\title{
Lifting the smokescreen of science diplomacy: comparing the political instrumentation of science and innovation centres
}

Elisabeth Epping ${ }^{1 凶}$

The notion of science diplomacy (SD) has increasingly gained momentum in recent years, however, it remains an empirically largely underexplored topic. This paper contributes to the study of SD by taking an instrument-centred perspective and focusses on science and innovation centres (SIC), a novel policy instrument in the science diplomacy toolbox. SIC are distinct units or satellite institutes, established by governments abroad, operating at the nexus of higher education, research, innovation, and diplomacy. Based on a comparative analysis, this article examines the rise of SIC in Germany and Switzerland. By means of applying a policy instrumentation lens, the career and development of the two SIC is retraced and insights are generated into their political instrumentation. Doing so contributes to unfold the blackbox of what is generally labelled as SD. In-depth interviews and analysis serve as the empirical foundation of this study. Ultimately, the results of this policy instrument study uncover the similarities and differences in SIC development and reveal their political instrumentation over time. It becomes evident that the objectives linked to SIC, and hence $\mathrm{SD}$, are clearly motivated by national needs. Furthermore, notions of SD are reflective of a certain Zeitgeist that is mirrored in the design of an overall, new, policy yet also marks a relabelling of long-existing practices. This study, accordingly, contributes to the knowledge base of SD as it enhances the scholarly understanding of SD instruments in terms of history, actors and political instrumentation while also offering a theoretical anchoring.

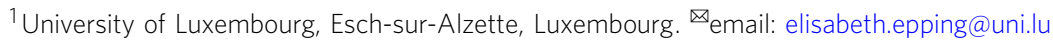




\section{Introduction}

cience diplomacy (SD) is a much-discussed concept and possibly a new paradigm to public policy. It rests on the key assumption that science and diplomacy form a mutually beneficial relationship so that both elements are able to nourish and stimulate each other (The Royal Society and AAAS, 2010). SD considers science to be a vehicle to foreign policy goals by addressing the pre-political room in the sense of operating as a depoliticising element, and unfolding impact in different ways than traditional diplomacy ${ }^{1}$ can (Cooper, 2013a; Sending et al., 2011). Most frequently, SD is defined as (The Royal Society and AAAS, 2010): (1) Science in diplomacy, understood as providing scientific advice to foreign policy; (2) Diplomacy for science encompasses promoting international research and science cooperation, both strategically top-down and bottom-up approaches. A prominent example of such an endeavour is the large-scale research infrastructure like the Large Hadron Collider at the European Organization for Nuclear Research (CERN); (3) Science for diplomacy assumes that science unfolds impact and operates as an element of soft power, as coined by Nye (2008), in international relations particularly in situations where diplomacy with its traditional tools, such as for instance negotiations (Constantinou and Sharp, 2016, p. 14) has come to a hold. Soft power in relation to science for diplomacy rests on "its attractiveness and influence both as a national asset, and as a universal activity that transcends national interests" (The Royal Society and AAAS, 2010, p. 11). Even more so, science is assumed to unfold potential as a tool of soft power, given its neutral and nonpolitical character, that "if aligned with wider foreign policy goals [...] can contribute to coalition-building and conflict resolution" (ibid. p. vi), making it an "effective agent" in international relations (Flink and Schreiterer, 2010, p. 665). Thereby, one might distinguish between SD as a set of distinct policies (Flink and Schreiterer, 2010) and SD as a practice (Fähnrich, 2015; Rüffin and Schreiterer, 2017). A more recent, yet less prominent, definition distinguishes and aligns SD according to the focus of national activities (Gluckmann et al., 2017, p. 3): (1) a country's domestic needs, (2) cross-border activities and (3) towards global challenges.

While SD has received growing attention among policy makers and scholars, there are two main challenges to its current use. First, the concept of SD seems to be a moving target, a concept with loose boundaries that is increasingly used as a catch-all concept in different fields (cf. Davis and Patman, 2015; Kaltofen et al., 2018). For example, these fields include grand challenges like climate change (Milkoreit, 2015; Ruffini, 2018), arctic governance (Berkman et al., 2011; Goodsite et al., 2016) or the governance of the internet (Mansell, 2018). However, there is no common understanding of SD and instead it is framed by a multitude of expectations and meanings among different actor groups (Flink and Rüffin, 2019; Flink and Schreiterer, 2010, p. 669) even within the same country (Flink, 2020). Besides this boundary challenge, a second point of concern is the lack of empirical evidence surrounding its study. The majority of contributions opt for an "explanation by naming" approach (Sending et al., 2011, p. 534), constituting a typical pattern of new diplomacies (cf. Constantinou et al., 2016), however, a misleading one. The normative prospects of SD transcending national interests and mobilising soft power are simultaneously used as an explanatory element in the debate. SD is accordingly increasingly considered to serve as a silver bullet to all sorts of problems (cf. Flink and Schreiterer, 2010). The lack of empirical evidence leads to a rather paradox situation where the importance of science to international relations is highlighted, yet "the scientific method is rarely applied to study science diplomacy" (Smith III, 2014, pp. 829-830). In other words, "the prevailing view that science diplomacy increases international trust and transparency rests on poor theory and weak evidence" (ibid.). Hence, the current use of SD bears signs of a conceptual overstretch and threats of it becoming a hollow concept and an empty signifier (Laclau and Mouffe, 2014).

Considering these backdrops, this paper empirically contributes to the study of SD by conducting a policy instrument study that is guided by the premises of policy instrumentation research. Doing so allows to accept the multitude of SD definitions while offering a theory-driven way to mitigate and handle SD's boundary challenges. Policy instrumentation literature stresses the decisive role of policy instruments for understanding overall public policy (Lascoumes and Le Galès, 2007; Saurugger, 2014). The article makes use of this argument and selects an instrument in practice enabling to unravel this catch-all concept. To allow for such an analysis, science and innovation centres (SIC), a novel policy instrument in the SD toolbox, are selected as they mark a distinct case on their own. SIC are an underresearched policy instrument that is considered by scholars and practitioners alike to be an innovative and unique instrument in the SD toolbox (cf. Berg, 2010; Epping, 2018; Federal Department of Foreign Affairs, 2010; Flink and Schreiterer, 2010). The article pays tribute to this novelty and aims to distil the motivations, beliefs, reasons, "the interests implicated in the choice of instruments" (Lascoumes and Le Galès, 2007, p. 9 drawing on Peters), in short the political rationales linked to SIC as well as its instrumentation. Uncovering the political rationales marks a logical starting point to the analysis of this new institutional form as this contributes to a much-needed understanding of SD. To specify, the normative prospects driving the SD concept are scrutinised in this study. It is argued that the spectrum of rationales linked to SIC is richer than conventionally conceived and promoted in the literature, stressing mainly soft power objectives (cf. Almeida Domingues and Ribeiro Neto, 2017; Turekian et al., 2015). An exception to this is the seminal comparative work by Flink and Schreiterer (2010, p. 669) who identify three goals linked to SD strategies: access to resources in order to raise national capacities, promotion of national achievements in research and development, and influence of the public opinion.

In response, this study conducts a systematic, comparative analysis of SIC operated by two countries namely Germany and Switzerland in order to unravel its political use and hence unfold the blackbox of what is labelled as SD. This contribution is organised as follows: The next section provides conceptual clarity on key concepts and illustrates the theoretical underpinning of the paper. The "methodology: case selection and data" section explicates the methodological principles that guide this research. Section "a novel policy instrument: science and innovation centres" introduces and defines SIC as a novel policy instrument. The empirical data for the two cases are presented in sections "SIC in Germany: German Centres for Research and Innovation/ Deutsche Wissenschafts- und Innovationshäuser (DWIH)" and "SIC in Switzerland: swissnex". This is succeeded by a comparative discussion of the similarities and differences in the instruments' development as well as its instrumentation. Ultimately, the results are discussed particularly considering the conceptual shortcomings of the SD debate.

\section{Conceptual framework}

Policy instrumentation. The analytical perspective used in this research corresponds to a trending approach in the study of policy instruments (Capano and Howlett, 2020; Hood, 2007; Lascoumes and Le Galès, 2007; Margetts and Hood, 2016). While classically, the literature considered policy instruments as being 
merely the outcomes of policy processes (cf. Howlett, 2000), the approach taken in this paper marks an inversion to that thinking. The inversion lies in the assumption that policy instruments are key for an understanding of public policy as they are institutions in a sociological sense that possess distinct rules and values and hence govern interactions (Lascoumes and Le Galès, 2004, 2007). This understanding is also reflected in the definition of policy instruments:

"a device that is both technical and social, that organises specific social relations between the state and those it is addressed to, according to the representations and meanings it carries. It is a particular type of institution, a technical device with the generic purpose of carrying a concrete concept of the politics/society relationship and sustained by a concept of regulation" (Lascoumes and Le Galès, 2007, p. 4).

Assuming that instruments are social devices possessing organising functions in the sense of an institution exceeds dominant and widespread views of instruments as purely technical tools (cf. Howlett, 1991). Lascoumes \& Le Galès move a step further and argue that instruments might develop a life on their own (for a similar argument see Voß and Simons, 2014) and create effects, differently from what policy makers anticipated in the first place. This is because they carry meanings, embody frames and accordingly create a certain perception of the issue (Kassim and Le Galès, 2010). They hence "structure or influence public policy" (2007, p. 8; Saurugger, 2014). In line with these premises, the authors argue for policy instrumentation:

"means the set of problems posed by the choice and use of instruments $[\ldots]$ that allow government policy to be made material and operational. Another way of formulating the issue is to say that it involves not only understanding the reasons that drive towards retaining one instrument rather than another, but also envisaging the effects produced by these choices" (2007, p. 4).

To that end, the analysis of the instrument's constituencies, but also its application, use and development are key for analysis. Given that, in politics, it often proves easier to agree on a certain instrument rather than on objectives, focusing on policy instrumentation shall lift the "smokescreen" of objectives, i.e., political rationales that are connected to a certain instrument. This reveals the "invisible-hence depoliticised-dimensions of public policies" (Lascoumes and Le Galès, 2007, p. 7) and allows to point to policy change. To put it another way, it shows "what is at stake politically in a particular policy field" (Bache, 2010, p. 59).

Empirically, applying the concept of policy instrumentation comes close to a deconstruction exercise. Policy instruments are analysed in terms of context and history because a certain longevity considering for instance governmental changes is noticeable. Hence, the analytical focus comprises the "long-term political careers of policy instruments, to analyse the debates surrounding their creation and introduction, the ways they were modified, the controversies" (Lascoumes and Le Galès, 2007, p. 17). To specify, instrumentation connects the development and choice of the instrument with its implementation to see how the instrument is used and understand the effects this produces. Instrumentation outputs encompass the procedural dimension in terms of "instruments, budgets, rules, norms and standards but can also be "medium and long-term in terms of (in) ability of policies to organise a policy field and influence social behaviour through conflict resolution, the allocation of resources and the imposition of sanctions" (Le Galès, 2016, p. 518). In particular, three types of instrumentation effects can occur (Lascoumes and Le Galès, 2007; Lascoumes and Simard, 2011): (1) aggregation effects, in the sense that the instrument brings together heterogeneous actors that work together and requires a modification of their initial positions. This eventually leads to inertia effects (given tensions between users-actors) and makes the instrument resistant to change; (2) representation and problematisation effects: the instrument leads to a particular framing of the issue which in turn creates a direct cognitive effect and suggests a certain explanatory system; (3) appropriation effects: instruments are inextricably embedded in a particular context and hence subject to an "appropriation by actors". Appropriation thereby refers to, for instance, offering a platform for professional mobilisations (i.e., "affirmation of new competencies"), reformulations (i.e., "serving particular interests and power relations between the actors") or even resistance to reduce or circumvent the impact of the instrument (Lascoumes and Simard, 2011, pp. 14-16).

Adopting a policy instrumentation approach supplements and advances classic instrument research (cf. Capano and Howlett, 2020; Kassim and Le Galès, 2010) as it stresses the uniqueness of instruments in terms of being an institution that possesses its own regularities and shapes public policy in its own way. Following the outlined intellectual paths, this research comparatively focusses on the historical development of two SIC, a valuable contribution in itself, and reconstructs as far as possible the context within which SIC emerged, the trajectory of the instrument and the debates that informed their evolution. Furthermore, the analysis will point to instrumentation effects.

Political rationales and policy-making. A crosscutting element in this research endeavour is the identification of (changing) political rationales throughout the instrument's trajectory. Political rationales are understood as goals, motivations and reasons that are formulated by state actors such as governments and appointed officials, i.e., bureaucracies, such as ministries, implying that the state is not treated as a unitary actor in this research. To describe and analyse these objectives, though acknowledging in line with the political sociology approach to instruments that they are not static, the actor centred institutionalism (ACI) as invented by Mayntz and Scharpf (1995) offers a valuable research lens. This is because its framework and categories point the researcher to certain aspects of reality related to decision-making, particularly in terms of corporate actors such as ministries (Treib, 2015) while also leaving room for policy entrepreneurs (Gunn, 2017; Leca et al., 2009). ACI rests on the premises that policy decisions can be explained by looking at the interplay of the following elements: actor constellations, actor orientations and interaction patterns. Actors, both individual and collective, are considered as being intentional and aiming to maximise their interests (Treib, 2015, p. 283). They are equipped with a basic self-interest (Scharpf, 2000, p. 64), that is formed and influenced by the institutional context. In line with the aim to identify the political objectives that guide SIC, the focus on actor constellations and orientations, i.e., "perceptions and preferences" are relevant categories (Scharpf, 2000, p. 51) for the subsequent analysis.

This heuristic is supplemented by concrete assumptions about governmental decision-making in line with the bureaucratic or governmental politics approach (Allison, 1968; Bendor and Hammond, 1992). The model specifies that decision-making capabilities rest with political actors, such as ministries or other units, hence transposing the idea of the state as a unitary actor with a distinct national interest. A peculiarity of the approach lies in the assumption of how decision-making takes place. Political actors, at times, favour policies that benefit their own organisation predominantly and often national interests, secondly. 
Accordingly, policy outcomes can be understood as bargaining exercises between governmental actors, as compromises, resulting from competition between actors possessing state responsibilities (Jones, 2010). In line with these assumptions, decision-making cannot be understood as strictly rational in terms of national interests. In other words, "intra- and inter-bureaucratic conflicts" are not uncommon (Howlett and Ramesh, 2003, p. 69) and political actors within a system and ministries, cannot be considered as homogenous. Analytically this requires identifying the state actors involved in the installation and operation of SIC. Further, it cannot be assumed that their (initial) motivations related to decision-making processes are fully revealed given that policy outcomes might be the result of bargaining exercises. In addition, and in line with re-conceptualising instruments as institutions, the gradual institutionalisation of the instrument might have shaped actor perceptions and hence accounted for its development as explained in the representation effect. The methodological set up accounts for this by applying a triangulation combining the analysis of official publications and expert interviews. In combination, the ACI and the bureaucratic politics approach inform this research by offering a research lens and generating insights on the logic linked to ministerial politics and hence the formulation of political rationales. Having said so, the next section specifies the methodological architecture of this study.

\section{Methodology: case selection and data}

The study derives from a qualitative, comparative case study approach (Gupta, 2012; Smelser, 2003), beneficial for numerous reasons. To start with, a comparison facilitates a characterisation of SIC as a novel institutional form in a way that it enables an elucidation of "features of a larger class of similar phenomenon" (Gerring, 2004, p. 341). Looking at two instances allows to gain deeper understanding of the phenomenon at hand (Heidenheimer et al., 2005). In addition, comparative approaches enable to establish "empirical connections between the characteristics of the system and the phenomenon under investigation" (Gupta, 2012, p. 12). To these means, Germany and Switzerland are selected as insightful cases as they resemble similarities in terms of their federal structure, their strong and renowned higher education and science system and their ranking as being highly innovative countries. Further, both countries have been operating SIC for several years, i.e., 19 years and 10 years, respectively, allowing for an analysis of the development of the instrument and hence policy instrumentation. However, the SIC differ regarding the core topics and themes, the governance structure and the funding model as will become evident in the following.

For this research, two types of data sources are sampled: (1) 20 publicly available policy documents, such as governmental strategies, annual reports, in addition to two speeches. To supplement these and allow for triangulation (Flick, 2011), (2) 13 semistructured expert interviews and several oral communications resting on narrative elements (Helfferich, 2011) enlighten this study ${ }^{2}$. The interview partners in Germany and Switzerland were purposively selected and include current and former state officials involved with SIC and key stakeholders from research and science organisations. The latter group is included for contextualisation and triangulation reasons and given the fact that in the case of Germany, the SIC's installation phase largely misses publicly available documentation. Most interviews (40-95 min each) were conducted face to face, while also a few took place via the phone. Combined, these two sources inform the history and development of the instrument as laid out previously and allow for triangulation. A thematic analysis of these sources was conducted to distil the leading political rationales (Braun and Clarke, 2006; Gioia et al., 2013). On the side of limitations, constraints of document analysis such as availability, completeness, and quality are acknowledged (Bowen, 2009; Rapley and Rees, 2018) while also limitations of interview methodology apply (Flick, 2018; Helfferich, 2011).

\section{A novel policy instrument: science and innovation centres}

Science and innovation centres are a unique policy instrument, which was increasingly adopted by innovative countries over the course of the past two decades. Among these countries are for instance Denmark (Innovation Center Danish), Germany (German Centres for Research and Innovation), the United Kingdom (Science and Innovation Network) and Switzerland (swissnex), scoring high in the Global Innovation Index (Cornell University et al., 2018). The exact national SIC expressions differ in a wide range of dimensions, such as their tasks, thematic focus (business entry, higher education, research cooperation etc.), organisational setup and governance structure. In addition, differences relate to the funding model (partly /fully government funded vs. publicprivate partnerships), the form of its presence abroad (housed by consulate/embassy vs. own office) and, according to Berg, to the type of staff that works in SIC, i.e., diplomatic vs. seconded vs. recruited staff (2010, pp. 69-70). SIC are also referred to as science diplomacy networks (Berg, 2010) or science and innovation diplomacy agencies (Rüffin, 2018). This study, however, deliberately advocates the use of the term SIC for three reasons: it allows for a stronger content-driven labelling, unties the instrument from immediate (science) diplomacy notions while not neglecting these, and offers a description that is closer to the original names in the different countries (which do not render immediate notions of diplomacy).

For several reasons, SIC constitute a notable policy instrument (cf. Epping, 2018) ${ }^{3}$. To start with, SIC typically have the promotion of national higher education, research and innovation systems in a holistic way at their hearts (cf. Fetscherin and Marmier, 2010). As such they are located abroad and work as a one-stop solution agency representing a streamlined coverage of their national ecosystem. This development is novel given that in most countries, international presences of respective national actors have been scattered, so far. Owing to their integrated approach, SIC bring added value to the visibility of the national higher education, research, and innovation system, while also enabling individual actors/institutions to gain from this new visibility. Among their tasks are, for instance, to provide expertise to higher education and research institutions, to find partners abroad or set up cooperation programmes, thereby responding to global collaboration trends (Powell, 2018, 2020). As SIC are typically well connected with both the host and the national system, they possess valuable expertise and experience that is key for operating abroad. Furthermore, SIC often have access to or maintain a certain infrastructure abroad such as own premises, mailing lists, ideally a good reputation and an established local network of researchers, policy makers, expats etc. These resources can easily be accessed by pertinent national actors of the education, science and innovation ecosystem in relation to their own activities abroad and responding to calls for internationalisation (cf. Altbach et al., 2009; Carlsson, 2006; Edler and Fagerberg, 2017; Wit et al., 2015). SIC function as a low threshold platform to those actors wishing to launch certain (internationalisation) activities.

All SIC are closely linked to ministries of foreign affairs and tied to the national diplomacy umbrella by varying degrees (cf. Berg, 2010). The most obvious link concerns the financial and administrative responsibility: SIC are under the auspices of the ministries of foreign affairs, though conjointly with sectoral 
ministries. The Swiss SIC for instance is part of Switzerland's external diplomatic representation, reflecting the decisive role of SIC to foreign policy. Also, the SIC's CEOs often hold diplomatic status as in the cases of Denmark and Switzerland. Finally, SIC might be physically linked to diplomacy as they often share their address with consulates or embassies underlining the close links. This organisational setup is noteworthy as internationalisation activities have traditionally been the responsibility of the respective sectoral ministry. While admittedly the promotion of national interests is the ministry of foreign affairs' core task, this explicit promotion of higher education and research, as in the case of SIC, marks a novelty and nourishes the SD paradigm.

A final distinct element is their networking function (cf. Berg, 2010). SIC aim to connect scientific communities of the host and home country by, for example, offering lecture series on current topics, or hosting academic and informative events for scientific communities. SIC also themselves operate in a network structure as countries typically run more than one SIC across the globe. Among the destinations are key tech hubs like New York and San Francisco (United States), but SIC are also in emerging markets like the BRICS ${ }^{4}$ countries. Given all the characteristics outlined above the author parsimoniously defines SIC as: distinct units or satellite institutes, established by governments abroad, operating at the nexus of higher education, research, innovation, and diplomacy. Thereby, SIC typically operate in a network structure.

\section{SIC in Germany: German Centres for Research and Innovation/Deutsche Wissenschafts- und Innovationshäuser (DWIH)}

DWIH in short. In 2009, the Deutsche Wissenschafts- und Innovationshäuser were launched within the framework of the research and academic relations policy ${ }^{5}$ (RARP) (Auswärtiges Amt, 2009b, p. 11), though their actual operations started in the subsequent three years. In total, five DWIH were opened in, Sao Paulo (Brazil), New Delhi (India), Tokyo (Japan), Moscow (Russia) and New York (United States). A sixth location of the network was Cairo (Egypt), though not officially labelled (and viewed by all stakeholders) as a DWIH. In the end of 2016, the Cairo location was closed following the results of an external evaluation. The current network is composed of the previously mentioned five locations aiming to "increase the visibility of German innovation leaders around the world [...] raise awareness of the German science, research and innovation landscape, advise scientists in Germany and the host countries, and connect actors at the local level" (DWIH-Netzwerk, 2019). The DWIH shall represent the German science and research system in close cooperation with key stakeholders known as the Alliance of Science Organisations ${ }^{6}$, but also several industry and business representatives. Politically, the DWIH are situated in the foreign affairs realm, while the overall management responsibility and coordination is in the hands of the German Academic Exchange Service (DAAD), an intermediary organisation of the Federal Foreign Office (FFO) and a quasi-policy maker (see Table 1). Historically, the FFO relies strongly on intermediary organisations when it comes to the management of its programmes (Harnischfeger, 2007). All five locations are overseen and steered by central governing bodies involving the key stakeholders. The DWIH are institutionally funded by the FFO accounting for approximately 2.5 million $€$ for all five locations.

The development of the instrument. The development of the DWIH reveals two distinct phases: (1) the conceptualisation phase and early days surrounding the opening of the DWIH
(2008-2016), and (2) the time after the reorganisation in 2017 until today.

Phase 1: the early struggles. The DWIH were launched publicly in 2009 at a jointly organised conference of the FFO and the Federal Ministry for Education and Research (BMBF), signalling the start of a new line in foreign policy: research and academic relations policy (Auswärtiges Amt, 2009a). The RARP aimed to support international networking exercises and promote Germany's strong science and innovation system abroad (Auswärtiges Amt, 2009b). To that end, around 43 million Euros were made available by the FFO (Auswärtiges Amt, 2009b; Deutscher Bundestag, $2010)^{7}$. The debate surrounding the creation of the DWIH or a joint representation abroad of Germany's research ecosystem in general, started however earlier (cf. Steinmeier, 2008, 2009) and seemed to be triggered and decisively influenced by the ideas of a few individuals, policy entrepreneurs (cf. Schütte, 2006). Even more so, the installation of DWIH is directly linked to the rise of SD discussions (Schütte, 2006, 2008, GIS2) and was inspired by developments in other countries, among which Switzerland (GIS2, SIS4). Around early 2008, the FFO approached key science and research stakeholders with the idea to develop DWIH. While in principal being an instrument that would benefit the ecosystem, this phase did not occur without friction and sources reveal that the design of the DWIH marked a tug-of-war, on different levels, between the actors involved (Borgwardt, 2009; GIS2, GIW5, GIW6, GIW8).

First, disagreement existed between the participating ministries, $\mathrm{FFO}$ and the sectoral ministry BMBF (having been led by different parties at the time). The BMBF was irritated and upset by the political push of the FFO to launch the RARP (GIS2, GIW6). Although they officially participated in the early deliberations the FFO had initiated (Steinmeier, 2008), the BMBF considered the DWIH as belonging to their policy domain, rather than the FFO's. Key stakeholders perceived this tension as omnipresent throughout the development and considered themselves to be a cue ball in the ministerial battle (GIW6). On a second level, struggles between the research and science organisations and the FFO became evident. The discussions circulated around the tasks and the exact model of the DWIH. Sources reveal that the parties involved had partially opposing views regarding these points and reaching agreement was not always easy (GIS2, GIW5, GIW8). To illustrate, among the initial ideas was to open a DWIH in Beijing, China. That option was, however, dropped soon given that the Deutsche Forschungsgemeinschaft (DFG), a strong stakeholder, did not agree on doing so as the Beijing office constituted a symbolic and special case for the DFG (Borgwardt, 2009). This is only one of many examples reflecting how actors' preferences impacted the gradual institutionalisation of the DWIH. A common, persisting, fear among stakeholders was the potential loss of visibility as a distinct individual actor. Actors did not want to be subsumed under the DWIH label solely or the diplomatic umbrella in general (GIW5, GIW6, GIW8). Third, there was disagreement, possibly mistrust, between the organisations themselves particularly visible in relation to the question of governance: i.e., who should oversee and govern the DWIH. Initial proposals suggested the DAAD to be in charge, however this did not resonate in overall approval (GIS2, GIW5, GIW8) and was hence discarded in favour of a model placing the leadership of the DWIH in the hands of consortia of the key stakeholders. At the end of these negotiations the institutional structure of the DWIH had been formalised.

Politically, the DWIH were considered a hallmark of the RARP that should strategically contribute (1) to showcase Germany as an innovative country and promote German know-how abroad, (2) to facilitate networking between German and international 


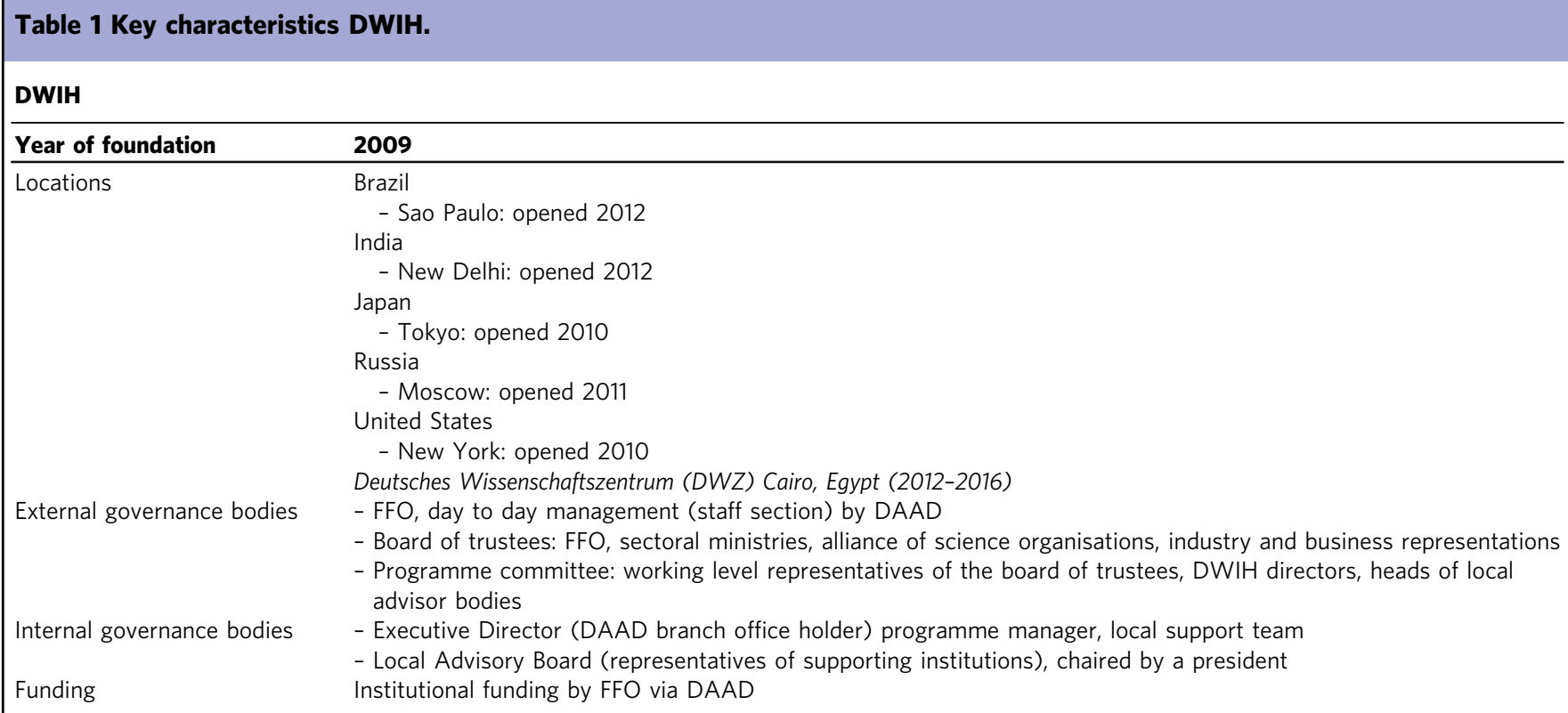

researchers and (3) to operate as a point of contact and information for both national and international actors (Steinmeier, 2009). Given that Germany is scarce on natural resources, investing in education, research, and innovation was considered particularly relevant for securing Germany's position in the future (GIS1, GIS2, Ammon, 2009). From the start, the DWIH were designed as an integral component of foreign policy and even conceived as a new twist given its focus on building bridges and fostering peace (Steinmeier, 2009). The urgency for this strategic adjustment was explained by external "shocks" and turning points such as the financial crisis in 2009 and global challenges like climate change to name a few. Politics explicitly acknowledged the outstanding reputation of Germany's research and science sector and the potential it has to reach "global elites and brains" and hence exert influence (GIS2, GIS4, Steinmeier, 2009), therefore being the win-win counterpart to real-politics (Ammon, 2009). This interconnectedness with foreign policy is repeatedly stressed in governmental documents while remaining vague on the exact goals it should respond to (cf. Auswärtiges Amt, 2013; Deutscher Bundestag, 2010, 2011).

Phase 2: reorganising the network. A slight turning point to the political framing of the DWIH is evident in $2016^{8}$. The FFO's annual report on cultural and educational activities reinforced Germany's pioneering role in addressing global challenges (Auswärtiges Amt, 2016) and pointed to the pertinent role of ideas and exchange in relation to economic and societal innovation and growth. The RARP, and hence DWIH, are considered as major tools to these ends. The document sets the increase of the percentage of international researchers in Germany as an additional objective, however, remains implicit as to whether the DWIH shall respond to this as well. Finally, the potential and the importance to address pre-political spaces are mentioned, as also addressed by the RARP. Altogether, the report mirrors classical components of the knowledge society in relation to RARP and adopts this framing most explicitly. Previous and subsequent documents instead focus stronger on the goals of profiling Germany as a strong research country or the strengthening of networks (cf. Auswärtiges Amt, 2017, 2019).

2016 marked a turning point for the overall network as well. The legitimacy and general existence of the DWIH were questioned by the federal audit office, because of the failure of the DWIH to finance themselves (Bundesrechnungshof, 2013). This has been an initial design principle, though contested (GIW5). Responding to this critique an evaluation was conducted underlining the value of the DWIH. However, it called for a) a reorganisation, in terms of stronger top-down management, to improve the efficiency of the houses (GIS3) and b) for revised funding arrangements. Moreover, the Cairo office was closed (Auswärtiges Amt, 2017), considered by some sources as a political pawn sacrifice. The overall reorganisation did not concern the actual tasks but resulted in a streamlined appearance and coordination of activities of the different locations which had until then been operating quite differently (GIW6). Another change marked the transition from annual programme funding to institutional funding. As of today, the RARP is still in place and considered to play an ambassador role for Germany (GIS3).

\section{SIC in Switzerland: swissnex}

Swissnex in short. One of the first countries to open a SIC was Switzerland. In 2000, the Swiss house for advanced research and education (SHARE) was opened in Boston (US), today better known as swissnex Boston (swissinfo.ch, 2000). This event signalled the start of the creation of a wider network succeeded by the launch of a pendant at the West Coast, in San Francisco, only three years later. Following the blueprints of these two locations, an expansion occurred with similar locations being opened in Singapore (2005) and China (2007). In 2008, the four locations were subject to a branding exercising, firming under the swissnex label. A second expansion wave or consolidation phase led to the opening of swissnex India (2011) and Brazil (2014) and came to an end in 2015 with the closing of swissnex Singapore and its transformation into a Science Counsellor at the Swiss embassy in Singapore (Der Bundesrat, 2015). The closure was explained with the fulfilment of swissnex's initial mission, which was to strengthen the cooperation between the two countries (Staatssekretariat für Bildung, Forschung und Innovation, 2015, p. 6). This official view is contested by other sources indicating the State Secretariat for Education, Research, and Innovation's (SERI) pressure to respond to market dynamics and also given that the office was quite small (SIS4) and had limited financial means 


\begin{tabular}{|ll}
\hline Table 2 Key characteristics swissnex. \\
Swissnex & $\mathbf{2 0 0 0}$ \\
\hline Year of foundation & Brazil \\
\hline Locations & - Rio de Janeiro: opened 2014 \\
& - Sao Paulo (Outpost) \\
& China \\
& - Shanghai: opened 2007 \\
& - Guangzhou (Outpost) \\
& India \\
& - Bangalore: opened 2011 \\
& US \\
& - Boston: opened 2000 \\
& - New York (Outpost) \\
& - San Francisco: opened in 2003 \\
& Swissnex Singapore (2005-2015) \\
& + Science Counsellors in 20 countries (partially overlapping with swissnex ${ }^{\text {a }}$ ) \\
& - FDFA conjointly with SERI (thematic supervision) \\
& - Swissnex Committee \\
CEO (holding diplomatic status) and local team to support the work & public-private partnership model
\end{tabular}

aFor the sake of completeness, 20 Science Counsellors, partially funded by SERI and the FDFA are the second component of the swissnex network, though not focal in this paper. For an overview, see here: https://www.swissnex.org/locations/\#science-counselor-locations (last accessed October, 31st 2019).

(Allen, 2015), the options were either a closing or a strengthening of the office (SIW1). In the meantime outposts had been opened in Guangzhou, New York and Sao Paulo (Swissnex, 2016).

The current network consists of the above-mentioned five SIC and respective outposts and is conjointly governed by the Federal Department for Foreign Affairs (FDFA) and SERI, whereas the latter thematically oversees swissnex (see Table 2). Around 5.5 million $\mathrm{CHF}$ are provided for their operation, while the single locations run on a public-private partnership model. According to the website, swissnex aims "to support the outreach and active engagement of our partners in the international exchange of knowledge, ideas and talent" (Swissnex, 2019) while also promoting the image of Switzerland as an innovative country. Following a critical report of a performance audit, the network was scrutinised (Eidgenössische Finanzkontrolle, 2016; Schweizer Eidgenossenschaft, 2016) and another evaluation took place in 2019.

The development of the instrument. The development of the swissnex instrument, in terms of strategic goals and orientation, can be divided into three phases not necessarily corresponding to the development as portrayed above. The start of a new phase is linked to the political push of a new goal/narrative as visible in the policy documents.

Phase 1: brain drain and internationalisation responses. The incremental development of swissnex started in 2000 with the opening of SHARE Boston. The idea goes back to the initiative and pushes of a few key persons, policy entrepreneurs, being in turn supported by SERI (cf. Lombard Odier, 2011, SIS4). Accordingly, the process of designing SHARE Boston originated in a bottom-up way, still marking a distinct operation principle of the current swissnex. The opening of SHARE Boston was surrounded by two societal developments. First, the millennium period was dominated by the peak of globalisation and the internationalisation of higher education and research. As a consequence, many countries started to adopt policies that facilitate internationalisation processes in a more consolidated way
(Huisman and van der Wende, 2005). Secondly, the early 2000s also marked a time of increased international mobility and Switzerland was confronted with a brain drain situation given that many highly educated scientists moved to the United States, namely the Boston area, to advance their career (Eidgenössische Finanzkontrolle, 2016; Lombard Odier, 2011; Marmier and Fetscherin, 2010; swissinfo.ch, 2000). In addition, a significant number of Swiss companies had set foot in the United States.

In light of these circumstances, SHARE Boston was installed as a response and considered to be the first "scientific consulate" (swissinfo.ch, 2000). Among SHARE Boston's key missions was to provide a platform for the local Swiss expat community in order to give them a "roof" and keep them engaged with Switzerland (swissinfo.ch, 2000; SIS4). This idea was coupled with the goal to reverse Switzerland's brain drain situation (Marmier and Fetscherin, 2010). A third strategic vision was to be present abroad, initiate and maintain the ties between Switzerland and the US and serve as "contact liaison" (SIS4). Back then, it was deliberately chosen to keep this new instrument independent and outside the borders of classic diplomacy, apart from administrative ties, explained by the-seemingly-different cultures of scientists and diplomats (SIS4).

While different sources point to the brain drain situation this goal is not prominently picked up in national policy documents of that time (cf. Schweizer Bundesrat, 1998, 2002) and mentioned as a side note only. The Botschaft ${ }^{9}$ 2004-2007 (Schweizer Bundesrat, 2002) refers to a more salient issue, i.e., the need for internationalisation efforts in light of increased competition for talent (SIS4), thereby reflecting the knowledge society narrative. The Botschaft explicitly acknowledges the facilitating role that SHARE Boston and San Francisco (which had been opened in the meantime) play towards these ends. Additional emphasis is placed on the increase of the visibility of Swiss institutions and Switzerland. The creation and maintenance of networks, being swissnex' initial goals, are identified as vehicles to these means.

Phase 2: bilateral cooperation programmes and expansion. Following the blueprints of Boston and San Francisco, an expansion took place as seen in the installation of a location in Singapore 
(2005) and China (2007). Anchored in the Botschaft 2008-2011 (Schweizer Bundesrat, 2007), the now four swiss houses should serve as an instrument to strengthen ties with regions and countries that are scientific "heavyweights". While previously, the focus was on internationalisation efforts in general, assigning a crucial role to the two Swiss houses (Schweizer Bundesrat, 2002), the focus in Botschaft 2008-2011 has shifted towards highlighting the role of bilateral cooperation programmes in education and science. These bilateral cooperation programmes target key countries, among which North America, Singapore but also China. The Swiss houses are explicitly considered to play a facilitating role to these means. Particularly the new office in China is meant to address these goals and it is assigned a most prominent role for the valorisation of scientific, technological, and cultural achievements. The enlargement of the prevailing network of Swiss houses is explicitly mentioned as a strategic priority, though paying tribute to the need for improvements of the current structure.

Previous goals, such as to overcome the brain drain situation are not explicitly mentioned anymore in Botschaft 2008-2011 and the facilitation of internationalisation dynamics has shifted towards bilateral cooperation programmes. Hence, the goals of the instrument seem to have been subject to modification, possibly showing tendencies of layering. Succeeding policy documents (Botschaft 2012, Botschaft 2013-2016, Botschaft 2017-2020) repeatedly stressed the vital role that the now called swissnex network, plays for swiss international policy, while also serving as a blueprint for other countries. The documents confirm swissnex' key targets as the facilitation of international exchange between higher education institutions, scientists and swiss enterprises but also to position Switzerland, internationally, as a key player in education, research, and science.

Phase 3: science diplomacy and soft power. 2018 marks a turning point for swissnex' political goals, again. The international strategy for education, research, and innovation (Schweizer Bundesrat, 2018) confirms the (historic) connection between scientific cooperation and diplomatic relations (cf. Fleury and Zala, 2012; Jost, 2012). Swissnex is explicitly identified as a vehicle to these means, while still having the promotion of Switzerland and international visibility at its core (also SIS2, SIS4, SIS5). The international strategy renders the notion of SD ("Wissenschaft für die Diplomatie") by pointing to the neutral and non-political character of science. More specifically, science is referred to as enabling dialogue between countries and working as a bridge builder and hence swiss diplomacy can benefit from Swiss scientific excellence (EDA, 2019; SIS5). Swissnex, as having the facilitation of international cooperation at its heart, is explicitly identified as an instrument for diplomatic purposes stressing the neutral and non-political character of science. The publication of this document demonstrates that the SD character is, for the first time, most explicitly woven into the long-existing swissnex instrument. Notions of SD, as indicated at the outset, seem to work politically as a cover for the swissnex instrument. More generally, it was revealed that the development of swissnex has also been accompanied by differences in opinion between the two steering ministries, FDFA and SFBI. Though at first the FDFA was supposed to offer only the administrative support to the network, the topic became stronger connected to their portfolio (EDA, 2019).

\section{Comparing the development and instrumentation of DWIH and swissnex}

This section systematically compares the trajectory of the DWIH and swissnex (see Table 3 ) to assess its current shape and discern its political instrumentation over time and extract the political objectives that are tied to the instrument.

Development and institutionalisation of DWIH and swissnex. To start with, ample evidence reveals that the instruments had diverging points of departure and developed according to different logics. Swissnex started with a pilot office and developed quite rapidly during times when internationalisation was at a peak and Switzerland was exposed to a brain drain situation. The launch of swissnex is strongly linked to the ideas and pushes of policy entrepreneurs that seized opportunities. Hence the development of the instrument can be described as bottom-up driven with politics being in general supportive and giving leeway. These principles are reflective for swissnex's current way of operating. In contrast, the DWIH were politically initiated in a top-down manner by the FFO in response to global challenges, though admittedly also policy entrepreneurs participated in the process. The Swiss model thereby served as a forerunner and an inspiration for the FFO pointing to a policy transfer exercise. The five DWIH were opened at once and almost ten years after the launch of the first swissnex.

Looking at actor constellations (Mayntz and Scharpf, 1995), the swissnex network developed in the beginning largely outside the realm of daily politics, though being supported. The data reveal initial reservations among the key stakeholders in the early stages that, however, quite soon diminished. Besides the key policy entrepreneurs, the main actors throughout the development were the two steering ministries SERI and the FDFA, occasionally supported by the swissnex committee that was installed later. This lean management structure is also mirrored in the governance structure of swissnex: the network operates largely according to a bottom-up principle, granting the individual locations room to manoeuvre and to experiment (with some limits), marking a replication of the Swiss research and science ecosystem. The expansion of the network and its development seem to have occurred demand-driven. This pragmatic bottom-up approach, is a distinct paradigm of swiss education and research policy (Pasternack et al., 2016), and explains swissnex' shape and institutionalisation.

Turning to the actor constellations in Germany, a different picture is painted. The DWIH developed in response to (inter) organisational dynamics and against the background of strong strategic actor interests. The network of key research and science organisations played a vital role in the gradual institutionalisation of the DWIH, suggesting aggregation and appropriation effects. To specify, the "dominance of institutional interests" (Edler et al., 2010, p. 175) is regarded to be a distinct element of the German research and science ecosystem, in particular given key research and science organisations' decision-making autonomy, own (political) agenda, and vested interests they bring to the table (Stucke, 2010). This dominance of strategic interests and interorganisational dynamics seemed to have coined the DWIH's gradual institutionalisation. The data reveals that the institutionalisation marks a balancing act between actors aiming to maintain independence while giving in to some form of collectivity. As of today, the role of key stakeholders is still strong and has been reconfirmed in the latest reorganisation given their formalised participation in central governing bodies. The multitude of key actors in the governing of the DWIH also impacts the way the DWIH (can) operate, given vested interests and the challenge to manoeuvre between different poles, at times. These differences in actor constellations and roles might be linked to inherent system characteristics like the size of the countries as well as the rules of the game and mindsets. To illustrate, Switzerland is a relatively small country, people know each other 
Table 3 Comparing the development of SIC in Germany and Switzerland.

\section{Similarities}

- High overlap in SIC's geographical coverage

- Closure of a SIC: Singapore 2015 (swissnex) and Cairo 2016 (DWIH)

- Audit and evaluation exercise by financial authorities: development according to governmental logic

- Role of policy entrepreneurs

- Ministerial struggles

\section{Differences}

- Points of departure

- Bottom-up (swissnex) vs. top-down logic (DWIH) guiding the installation phases

- Incremental (swissnex) vs. simultaneous (DWIH) opening of SIC

- Embeddedness in the national system and involvement of actors: few (swissnex) vs. high number of strategic actors (DWIH) and "tensions are solved at the regular's table" (i.e., Stammtisch) (SIW1), easing policy initiation and formulation.

In terms of political actors, in both cases, there were struggles throughout the process between the two key ministries, foreign ministry and sectoral ministry for education and research, as also reflected in the bureaucratic politics model (Jones, 2010). These struggles were mainly linked to competence and visibility, captured as appropriation effects in the policy instrumentation literature, but also reflective of different institutional cultures. Both cases reflect that the foreign ministries played a decisive role in the process shown in the fact that the SIC (partially) belong to their portfolio while this is not self-evident. Admittedly, the role of the German FFO is even more striking given its agenda setting role and rather undivided thematic supervision, pointing to a case of appropriation and the affirmation of new competences. In which ways this "interaction" (Scharpf, 2000) has exactly influenced the institutionalisation of SIC and whether the setup of the SIC would have been different if the sectoral ministry would have been in the driver's seat instead, is subject to additional research and/or speculation.

Today, both SIC show a high overlap in terms of geographical coverage as being in high impact countries and emerging markets. Both countries also closed a SIC in the past, i.e., Singapore (2015) and Cairo (2016) and have been subject to critique and evaluation by federal audit instances. This development mirrors a certain convergence between the two cases and shows that a functional dimension, i.e., governmental need to demonstrate impact, is connected to the operations of SIC. Accordingly, the development needs to be understood as being shaped by functional governmental logics. As concerns the current institutionalisation of the two SIC, they seemingly respond to a similar goal, however, the exact set-up differs and can be explained by the previous struggles. In addition, the model for resource allocation varies between public (DWIH) vs. public-private (swissnex) financed, the governance model reflects a bottom-up (swissnex) vs. top-down (DWIH) management and the involvement of (political) actors can be characterised as low (swissnex) vs. high (DWIH).

Policy objectives and instrumentation. The political instrumentation reflects similarities and differences between the German and Swiss SIC. From the beginning, SIC were embedded differently in overall strategic (SD) policies: the German SIC were firmly anchored in a new foreign policy initiative while the Swiss SIC marked an innovative pilot exercise developed by policy entrepreneurs that operated under the umbrella of diplomacy. These diverging starting positions are reflective for the ongoing instrumentation of SIC. The application of the policy instrumentation lens to the development of the DWIH and swissnex suggests that the (SD) instrument is consolidating as an institution and led to distinct effects as will be shown in the following.

To start with the political objectives that are attached to SIC, the findings demonstrate that swissnex was quite rapidly utilised by political actors (SERI and Federal Council) as a vehicle for tackling different objectives such as promoting international cooperation and visibility (phase 1), classical notions of the knowledge society (phase 1), as well as the facilitation of bilateral cooperation agreements (phase 2). This instrumentation can be captured as access and promotion, following Flink and Schreiterer (2010). In a similar vein, only recently did official policy documents explicitly identify scientific cooperation as a valuable tool for diplomatic relations and referred to swissnex as an example (phase 3 ). In particular, reference to soft power and the exertion of influence were considered as objectives of swissnex, thereby also explicitly referring to SD. This instrumentation marks a shift away from the previous focus on access and promotion towards influence (Flink and Schreiterer, 2010) and might be explained by the evolving SD discourse in recent years and the governmental need to jump on this train. The data shows that swissnex was layered with various pressing political issues in the past and is reflective of the general "Zeitgeist", trends, and objectives of national politics, hence its environment. Turning to the political objectives of the German SIC, the data reflects that the DWIH were ab initio elements of foreign policy and embedded in an overall strategy. The promotion of international cooperation and the strengthening of networks were conceived as vehicles for foreign policy goals mobilising soft power and aiming for the exertion of influence. This mirrors the SD debate as indicated at the outset and comprises rationales grouped as access, promotion, and influence (Flink and Schreiterer, 2010). These objectives remain the leading ones for the DWIH over time and point to the existence of a certain explanatory system linked to DWIH, suggesting a representation effect. A slight amendment occurred when the economic dimension to which DWIH shall contribute, was politically particularly stressed (phase 2). This economic focus comprises classical notions of the knowledge society and points to domestic needs (Gluckmann et al., 2017), indicating that access rationales are strong.

The institutionalisation of the SIC pointed to various dynamics and effects that have partially been addressed already, confirming their distinct role. SIC, in their respective setting, seem to have impacted the organisation of the policy field and potentially influenced social behaviour of actors as visible in the three instrumentation effects that occurred at different stages throughout the instruments' trajectory (see Table 4). Given its long career, swissnex seems, over time, to have been connected with a certain cognitive effect as being a reliable instrument promoting various facets of international cooperation, signalling a representation and problematisation effect.

The continuous reshaping of swissnex' goals, depicts an appropriation effect in the sense that the instruments offers a platform for reformulations and serves particular interests, in this case governmental interests. Cautiously formulated, these changes do, however, not seem to lead to substantial changes in actual practices, though this should be analysed in more depth. In light 
Table 4 Political instrumentation SIC.

\begin{tabular}{|c|c|c|}
\hline & DWIH & swissnex \\
\hline $\begin{array}{l}\text { Embeddedness in overall } \\
\text { (SD) policies }\end{array}$ & -Ab initio part of a new foreign SD policy initiative & $\begin{array}{l}\text {-Innovative pilot exercise, explicitly linked to } \\
\text { notions of SD in } 2018\end{array}$ \\
\hline \multirow[t]{2}{*}{ Objectives linked to SIC } & -Access, promotion and influence & $\begin{array}{l}\text {-Access, promotion; influence explicitly } \\
\text { since } 2018\end{array}$ \\
\hline & -Stable political objectives & -Changing political goals \\
\hline $\begin{array}{l}\text { Aggregation effects (inertia } \\
\text { and longevity): }\end{array}$ & $\begin{array}{l}\text {-Diverse actors work together (for the initiation of the instrument) } \\
\text { with own interests and positions (tug-of-war) } \\
\text { In both cases: } \\
\text {-Instrumentation effects consolidate each other: SIC become self- } \\
\text { referential and link to an explanatory system (representation and } \\
\text { problematisation effect) that is difficult to change and strengthened } \\
\text { by a gradual institutionalisation, leading to inertia }{ }^{a} \\
\text {-Path-dependencies and concerns of international visibility }\end{array}$ & \\
\hline $\begin{array}{l}\text { Representation and } \\
\text { problematisation effects: } \\
\text { Appropriation effects: }\end{array}$ & $\begin{array}{l}\text {-Stable (SD) framing of the DWIH over time as an integral } \\
\text { component of foreign policy } \\
\text {-Affirmation of new competences in case of FFO }\end{array}$ & $\begin{array}{l}\text {-Considered a reliable instrument promoting } \\
\text { various facets of international cooperation } \\
\text {-Responsiveness to the environment and } \\
\text { continuous reformulations by political actors: } \\
\text { instrument serves as a platform }\end{array}$ \\
\hline & $\begin{array}{l}\text {-Tug-of-war between different actor groups (phase 1) } \\
\text { In both cases: } \\
\text {-Ministerial struggles (over competence) linked to the instrument } \\
\text {-Contextualisation of the instrument }\end{array}$ & \\
\hline
\end{tabular}

of evolving rationales swissnex reflects tendencies of longevity and a resistance against outside pressures such as critique by an audit instance, confirming its role as a solid institution. Adding to the theory, it seems that these two effects reinforce each other and might on their own explain inertia tendencies. To illustrate, the cognitive effect of the instrument is over time manifesting and consolidating in the environment. An institution once in place is, however, difficult to change and might hence explain why, even despite critique of an audit instance, the instrument remains in place and in fact does not dramatically change its way of operating. A similar effect can be seen in the case of the DWIH. The DWIH have been connected to a certain (SD) framing and respond to stable objectives over time (see previous section), pointing to a representation and problematisation effect. Hence the DWIH seem to adhere to the explanatory system as designed originally that might in fact have been the result of the initial bargaining exercise among heterogenous actors having to acquire a common understanding of the instrument (aggregation and representation effect). Over time, this shared cognition of the instrument is consolidating among the relevant actors and its environment and becomes difficult to change since it has become inextricably contextualised (appropriation effect). One might, accordingly, argue that the gradual institutionalisation of the instrument has shaped actor perceptions in such a way that it became resistant to outside pressures such as audit instances. This inertia can, in addition, be explained by the high and heterogenous number of actors involved, pointing to an aggregation effect. Accordingly, and adding to the theory, it became evident that the instrumentation effects often occur together and in fact reinforce each other leading to inertia.

To sum up, it can be observed that both SIC are inextricably embedded in a particular context, responsive to their environment and seem to consolidate as an institution. Given that the DWIH look back on a rather short history of only ten years, it is promising to see how the institutionalisation will further develop. It became evident that swissnex reflects changing political goals over time while the DWIH respond to relatively stable objectives. Eventually both countries explicitly consider SIC to be instruments of SD contributing to wider foreign policy objectives while also fostering international competitiveness and promoting international cooperation. Both instruments reveal a certain inertia regarding outside pressures, such as audit exercises (with some limits) and longevity. This holds true particularly in comparison to other funding instruments that are usually limited in time. Path-dependency aspects and the fact that new, unique and at times costly institutional structures are created might explain this inertia as well as, in the case of Germany, strong and diverse actor constellations. Closing a location creates a gap and might be understood as a political signal to the host country with respect to its (diminishing) political importance. The theoretical premises chosen to guide this study do not explicitly account for these two factors, yet they deem relevant. Particularly the concern of international visibility shows the limits of the political instrumentation approach since its explanatory power is linked to the national environment.

\section{Discussion and conclusion}

This research applied a comparative instrument-centred perspective to contribute to the SD scholarship. By shedding light on a novel and innovative instrument, SIC, a refined understanding of what is generally summarised as SD could be gained. To specify, the trajectory of the DWIH and swissnex has been retraced as well as its political instrumentation, i.e., the way the instrument has been used and the objectives and rationales it shall respond to. Despite, or maybe because of its size, but certainly because of its pragmatic, bottom-up approach, Switzerland pioneered in developing a unique and novel instrument that served as an inspiration and blueprint for several other countries, among which most clearly Germany. The analysis revealed that the SIC developed according to different logics that are reflective for the environment they operate in. These system characteristics also impacted the varying institutionalisation of the instrument and account for its differing structure and way of operating, indicating instrumentation effects.

Although both SIC are (nowadays) politically framed as an instrument targeting $\mathrm{SD}$, this has not always been the case for 
Switzerland. Swissnex was already long in place as a distinct and renowned instrument before it was re-branded and explicitly linked to SD in political documents, in 2018, not necessarily pointing to a change in practice. This reconfirms that while SD might be a new (political) trend, the practices it covers are not per se; as the proverb goes, old wine in new bottles. Whether this relabelling exercise creates certain advantages for domestic actors marks an avenue for further research. In sharp contrast to that stands the development of the DWIH. They were launched as part of a distinct policy package aiming to tackle and promote SD. Accordingly, the findings emphasise that on the one hand existing practices might be relabelled as $\mathrm{SD}$, demonstrating governmental responsiveness. On the other hand, the SD discourse might give rise to new and distinct policy responses. Whether governments opt for one or the other makes a difference in terms of assessing whether SD is merely a window-dressing exercise or whether it is reflective of a new policy paradigm.

The study identified that the instrumentation of SIC differs between the two countries and reveals political objectives that are richer than conventionally conceived in the literature. While the workings of soft power appear to constitute the leading narrative surrounding the overall debate, this research has reconfirmed that soft power is only part of the picture. Notably, the projection of influence, in the case of swissnex is only explicitly mentioned in 2018. For a comparatively small country, one would have expected this to be stronger interwoven with the instrument, considering the missing availability of natural resources and the subsequent need to be internationally competitive. The findings show that the scope of objectives ranges from economic aspects such as securing national competitiveness (knowledge society), to internationalisation efforts, to visibility and branding exercises, to the exertion of influence, as well as responding to global challenges. With the exception of responding to global challenges, these objectives can be subsumed under the rationales of access, promotion and influence. Altogether, these objectives mirror a clear national dimension and motivation and are firmly embedded in the logic of (scientific) global competition and cooperation. Hence, the findings contest the widely spread assumption that SD "transcends national interests" (The Royal Society and AAAS, 2010). Instead, domestic needs and interests are covered under notions of SD, thereby challenging SD's assumed win-win character and scrutinising its glorification of being a silver bullet. In other words, opening the blackbox of SD, in the case of SIC, reveals national interests to be in the front row.

To sum up, this study helps to understand the development of an innovative instrument (of SD), as well as its political instrumentation. The analysis pointed to elements explaining the gradual institutionalisation of the instrument, revealed the role of actor constellations and interactions and offered insights on how the instrument unfolded impact. In addition, the study displayed the richness of objectives that are grouped under the umbrella of SD. Approaching SD from an instrument-centred perspective has been fruitful to mitigate the boundary challenges linked to the prevailing use of the concept while being able to foreground its political instrumentation. In the words of Lascoumes and Le Galès (2007), the analysis of SIC lifted the smokescreen of SD and showed what (else) is at stake politically.

\section{Data availability}

The data sets generated during and/or analysed during the current study are to a limited extent publicly available. The sample of documents can be made available from the corresponding author on reasonable request. Restrictions apply to interview data given the sensitive nature of the research and missing consent of interviewees. As anonymity and confidentiality was guaranteed no interview data can be shared.

Received: 5 December 2019; Accepted: 8 September 2020; Published online: 30 September 2020

\section{Notes}

1 Traditional diplomacy (cf. Constantinou et al., 2016) refers to a rigid understanding of diplomacy in terms of actors, tasks and channels of communication (also known as club diplomacy) as opposed to new forms, modes of interaction and actors (Cooper et al., 2013b; Cooper, 2013a)

213 in-depth interviews were selected for analysis (including two interviews of the site visits, not listed below); they are part of a wider data collection exercise in relation to a larger research project. The interviews took place between June 2017-May 2018. Germany: Interviews GIS1, GIS2, GIS3, GIS4: current/former senior state officials, FFO; Interviews GIW5, GIW6, GIW8: senior representatives, key research and science organisations; Switzerland: Interviews SIS2, SIS3, SIS4, SIS5: current/former senior state officials, FDFA and SERIInterview SIW1: former senior representative, research and science organisation.

3 This section is informed by (1) a desk study on different national SIC that the author conducted (2) site visits and two interviews with SIC of Denmark and Switzerland (Nov. 2017) and (3) a consultation of the literature.

4 The BRICS countries are Brazil, Russia, India, China and South Africa.

5 Initiative Außenwissenschaft.

6 Members of the "Allianz der Wissenschaftsorganisationen" include: Alexander von Humboldt Foundation, German Academic Exchange Service, the German Council of Science and Humanities, German National Academy of Sciences Leopoldina, German Research Foundation (DFG), Fraunhofer Association, German Rector's Conference, the Helmholtz Association of German Research Centres, the Leibniz Association, and the Max Planck Society. https://www.dfg.de/en/dfg_profile/alliance/index.html (visited last 14.06.2019).

7 In comparison the Federal Ministry for Education and Research's overall budged accounted for $20.3 \mathrm{mrd}$. Euros in 2010 (Der Tagesspiegel, 2009).

8 Nota bene, interviews pointed to notions of the knowledge society already as motivations during the GCRI's design phase. However, this focus was not explicitly manifested in policy documentation prior to 2016

9 Botschaft are policy documents that determine the political goals, set the overall strategic direction and vision for the respective legislative periods and are typically published one or two years ahead of the period they address.

\section{References}

Allen M (2015) Swissnex to close Singapore office, swissinfo.ch

Allison GT (1968) Conceptual models and the cuban missile crisis: rational policy, organization process, and bureaucratic politics. P-3919, California. Accessed 18 Nov 2019

Almeida Domingues A, Ribeiro Neto PH (2017) Science Diplomacy as a tool of international politics: the power of "soft power". Braz J Int Relat 6(3): 607-629

Altbach PG, Reisberg L, Rumbley LE (2009) Trends in global higher education: tracking an academic revolution: a report prepared for the UNESCO 2009 World Conference on Higher Education, Paris. Accessed 29 July 2019

Ammon P (2009) Rede zur Auftaktkonferenz der Initiative Außenwissenschaft 2009, Berlin

Auswärtiges Amt (ed) (2009a) Wissenswelten verbinden. Deutsche Außenpolitik für mehr Bildung, Wissenschaft und Forschung: Konferenzdokumentation. Edition Diplomatie. Auswärtiges Amt, Berlin

Auswärtiges Amt (2009b) Wissenswelten verbinden.-Auftaktkonferenz zur Initiative Außenwissenschaftspolitik, Berlin

Auswärtiges Amt (2013) 16. Bericht der Bundesregierung zur Auswärtigen Kulturund Bildungspolitik 2011/2012, Berlin

Auswärtiges Amt (2016) 19. Bericht der Bundesregierung zur Auswärtigen Kulturund Bildungspolitik: Kultur, Bildung, Wissenschaft und Kommunikation in globaler Verantwortung, Berlin

Auswärtiges Amt (2017) 20. Bericht der Bundesregierung zur Auswärtigen Kulturund Bildungspolitik 2016: Menschen bewegen: Dialogräume schaffen Brücken bauen Perspektiven entwickeln, Berlin

Auswärtiges Amt (2019) 21. Bericht der Bundesregierung zur Auswärtigen Kulturund Bildungspolitik für das Jahr 2017: Zugang zu Kultur und Bildung: Kulturelle Freiräume schaffen und gestalten, Berlin. Accessed 31 May 2019

Bache I (2010) Partnership as an EU policy instrument: a political history. West Eur Polit 33(1):58-74. https://doi.org/10.1080/01402380903354080

Bendor J, Hammond TH (1992) Rethinking Allison's Models. Am Political Sci Rev 86(2):301-322. https://doi.org/10.2307/1964222 
Berg L-P (2010) Science diplomacy networks. In: Federal Department of Foreign Affairs (ed.) Swiss Science Diplomacy, 2nd edn. Politorbis, vol. 49, pp 69-74

Berkman PA, Lang, Michael A, Walton DWH, Young, Oran R (eds) (2011) Science diplomacy: Antarctica, and the governance of international spaces. Smithsonian Institution Scholarly Press, Washington D.C.

Borgwardt A (ed) (2009) Wissenschaftsaußenpolitik: Deutschland als Knotenpunkt im weltweiten Wissensnetzwerk; Konferenzbericht der Veranstaltung vom 13. November 2008 Friedrich-Ebert-Stiftung, 1. Aufl. Friedrich-Ebert-Stiftung, Berlin

Bowen GA (2009) Document analysis as a qualitative research method. Qual Res J 9(2):27-40. https://doi.org/10.3316/QRJ0902027

Braun V, Clarke V (2006) Using thematic analysis in psychology. Qual Res Psychol 3(2):77-101. https://doi.org/10.1191/1478088706qp063oa

Bundesrechnungshof (2013) Auswärtiges Amt: Wissenschafts- und Innovationshäuser des Auswärtigen Amtes tragen sich weiterhin nicht selbst. In: Bundesrechnungshof (ed) Bemerkungen 2013 zur Haushalts- und Wirtschaftsführung des Bundes, Bonn

Capano G, Howlett M (2020) The knowns and unknowns of policy instrument analysis: policy tools and the current research agenda on policy mixes. SAGE Open 10(1):1-13. https://doi.org/10.1177/2158244019900568

Carlsson B (2006) Internationalization of innovation systems: a survey of the literature. Res Policy 35(1):56-67. https://doi.org/10.1016/j.respol.2005.08.003

Constantinou CM, Kerr P, Sharp P (eds) (2016) The SAGE handbook of diplomacy. Sage, Los Angeles, London, New Delhi

Constantinou CM, Sharp P (2016) Theoretical Perspectives in Diplomacy. In: Constantinou CM, Kerr P, Sharp P (eds) The SAGE handbook of diplomacy. Sage, Los Angeles, London, New Delhi, pp. 13-27

Cooper AF (2013a) The changing nature of diplomacy. In: Cooper AF, Heine J, Thakur R (eds) The Oxford handbook of modern diplomacy. Oxford University Press, Oxford, pp. 35-53

Cooper AF, Heine J, Thakur R (2013b) Introduction: The Challenges of 21stCentury Diplomacy. In: Cooper AF, Heine J, Thakur R (eds) The Oxford handbook of modern diplomacy. Oxford University Press, Oxford, pp. 1-31

Cornell University, INSEAD, WIPO (2018) The Global Innovation Index 2018: Energizing the World with Innovation. Ithaca, Fontainebleau, Geneva, Accessed 19 Jun 2019

Davis LS, Patman RG (eds) (2015) Science diplomacy: new day or false dawn? World Scientific Publishing Co. Pte. Ltd., Singapore

Der Bundesrat (2015) swissnex Singapore schliesst die Türen, Bildungs- und Wissenschaftsbüro an Botschaft neu eröffnet, Bern

Der Tagesspiegel (2009) BMBF: Mehr Geld für Schavans Ministerium. Der Tagesspiegel

Deutscher Bundestag (2010) Bericht der Bundesregierung zur Auswärtigen Kulturpolitik 2008/2009, 17/970, Berlin. Accessed 16 Jul 2019

Deutscher Bundestag (2011) Bericht der Bundesregierung zur Auswärtigen Kulturund Bildungspolitik 2009/2010, 17/4413, Berlin. Accessed 16 July 2019

DWIH-Netzwerk (2019) Objectives. https://www.dwih-netzwerk.de/en/who-weare/objectives/. Accessed 27 Jun 2019

EDA (2019) Die Schweiz in der Welt 2028: Bericht der Arbeitsgruppe «Aussenpolitische Vision Schweiz 2028». Accessed 4 Nov 2019

Edler J, Fagerberg J (2017) Innovation policy: what, why, and how. Oxford Rev Econ Policy 33(1):2-23. https://doi.org/10.1093/oxrep/grx001

Edler J, Kuhlmann S, Stegmaier P (2010) Fragmentierung und KoordinationGovernance der Wissenschafts-und Innovationspolitik in Deutschland. In: Seckelmann M, Lange S, Horstmann T (eds) Die Gemeinschaftsaufgaben von Bund und Ländern in der Wissenschafts- und Bildungspolitik: Analysen und Erfahrungen. Nomos, Verlag, Baden-Baden, pp. 169-194

Eidgenössische Finanzkontrolle (2016) Wirtschaftlichkeitsprüfung des Aussennetzes für Bildung, Forschung und Innovation (Swissnex): Staatssekretariat für Bildung. Forschung und Innovation. EFK-15312, Bern

Epping E (2018) Science and Innovation Centers-bringing a new dimension to the internationalization of higher education, research and innovation. Accessed 5 Sep 2018

Fähnrich B (2015) Science diplomacy: investigating the perspective of scholars on politics-science collaboration in international affairs. Public Understanding of Science:1-16. https://doi.org/10.1177/0963662515616552

Federal Department of Foreign Affairs (2010) Swiss Science Diplomacy. Politorbis, vol 49. Accessed 3 Apr 2017

Fetscherin M, Marmier P (2010) Switzerland's nation branding initiative to foster science and technology, higher education and innovation: a case study. Place Branding and Public Diplomacy 6(1):58-67. https://doi.org/10.1057/ pb.2010.6

Fleury A, Zala S (eds) (2012) Wissenschaft und Aussenpolitik: Beiträge zur Tagung anlässlich des 50. Jubiläums der Schaffung des ersten Postens eines schweizerischen Wissenschaftsattachés. Diplomatische Dokumente der Schweiz, Bern, Quaderni di Dodis, vol 1

Flick U (2011) Triangulation: Eine Einführung. Qualitative Sozialforschung. Springer Fachmedien, Wiesbaden, VS Verlag für Sozialwissenschaften
Flick U (ed) (2018) The SAGE handbook of qualitative data collection. Sage, Los Angeles

Flink T (2020) Wissenschaftsdiplomatie in der Europäischen Union: Praktiken und Perspektiven. Forschung, Politik-Strategie-Management 1+2(2019):5-11

Flink T, Rüffin NV (2019) The current state of the art of science diplomacy. In: Cranzler W, Kuhlmann S, Simon D (eds) Handbook on science and public policy. Edward Elgar, Cheltenham, pp. 104-121

Flink T, Schreiterer U (2010) Science diplomacy at the intersection of S\&T policies and foreign affairs: toward a typology of national approaches. Sci Public Policy 37(9):665-677

Gerring J (2004) What Is a Case Study and What Is It Good for? Am Polit Sci Rev 98(2):341-354

Gioia DA, Corley KG, Hamilton AL (2013) Seeking qualitative rigor in inductive research. Organ Res Methods 16(1):15-31. https://doi.org/10.1177/ 1094428112452151

Gluckmann PD, Turekian V, Grimes RW, Kishi T (2017) Science diplomacy: a pragmatic perspective from the inside. Science Diplomacy, 6(4). Accessed 25 Jul 2019

Goodsite ME et al. (2016) The role of science diplomacy: a historical development and international legal framework of arctic research stations under conditions of climate change, post-cold war geopolitics and globalization/power transition. J Environ Stud Sci 6(4):645-661. https://doi.org/10.1007/s13412-0150329-6

Gunn A (2017) Policy entrepreneurs and policy formulation. In: Howlett M, Mukherjee I (eds) Handbook of policy formulation. Handbooks of research on public policy. Edward Elgar Publishing, Cheltenham, pp. 265-282

Gupta K (2012) Comparative public policy: using the comparative method to advance our understanding of the policy process. Policy Stud J 40(S1):11-26

Harnischfeger H (2007) Auswärtige Kulturpolitik. In: Schmidt S, Hellmann G, Wolf R (eds) Handbuch zur deutschen Außenpolitik. 1. Aufl. VS Verl. für Sozialwiss, Wiesbaden, pp. 713-723

Heidenheimer AJ, Heclo H, Teich Adams C (2005) The politics of social choice. In: Wiarda HJ (ed) Comparative politics: Volume VI Comparative Public Policy. Routledge, London, vol 6, pp. 13-36

Helfferich C (2011) Die Qualität qualitativer Daten: Manual für die Durchführung qualitativer Interviews. 4. Auflage. VS Verlag für Sozialwissenschaften/ Springer Fachmedien Wiesbaden GmbH Wiesbaden, Wiesbaden

Hood C (2007) Intellectual Obsolescence and Intellectual Makeovers: Reflections on the Tools of Government after Two Decades. Governance 20(1):127-144

Howlett M (1991) Policy instruments, policy styles, and policy implementation: national approaches to theories of instrument choice. Policy Stud J 19(2): 1-21. https://doi.org/10.1111/j.1541-0072.1991.tb01878.x

Howlett M (2000) Managing the "hollow state": procedural policy instruments and modern governance. Canadian Public Admin 43(4):412-431. https://doi.org/ 10.1111/j.1754-7121.2000.tb01152.x

Howlett M, Ramesh M (2003) Studying public policy: Policy cycles and policy subsystems, 2. ed. Oxford Univ. Press, Don Mills, Ontario

Huisman J, van der Wende M (eds) (2005) On cooperation and Competition II Institutional responses to Internationalisation, Europeanisation and Globalisation. Lemmens, Bonn, ACA papers on international cooperation in education

Jones CM (2010) Bureaucratic politics and organizational process models. In: Oxford Research Encyclopedias (ed.)

Jost HU (2012) Wissenschaft auf Aussenposten.: Eine Einführung zur Geschichte der Wissenschaftsattachés. In: Fleury A, Zala S (eds) Wissenschaft und Aussenpolitik: Beiträge zur Tagung anlässlich des 50. Diplomatische Dokumente der Schweiz, Bern, pp. 15-20. Jubiläums der Schaffung des ersten Postens eines schweizerischen Wissenschaftsattachés, 3.-4. Dezember 2008. Quaderni di Dodisvol 1

Kaltofen C, Acuto M, Blackstock J (eds) (2018) Special Issue: Science Diplomacy. Global Policy 9(53):1-80.

Kassim H, Le Galès P (2010) Exploring governance in a multi-level polity: a policy instruments approach. West Eur Polit 33(1):1-21. https://doi.org/10.1080/ 01402380903354031

Laclau E, Mouffe C (2014) Hegemony and socialist strategy: Towards a radical democratic politics, 2 edn. Verso, London, New York, Radical thinkers

Lascoumes P, Le Galès P (2004) Gouverner par les instruments. Sciences Po Gouvernance. Presses de Sciences Po, Paris

Lascoumes P, Le Galès P (2007) Introduction: Understanding Public Policy through Its Instruments-From the Nature of Instruments to the Sociology of Public Policy Instrumentation. Governance 20(1):1-21

Lascoumes P, Simard L (2011) Public policy seen through the prism of its instruments. Rev Fr Sci Polit (English) 61(1):1-17. https://doi.org/10.3917/ rfspe.611.0001

Le Galès P (2016) Performance measurement as a policy instrument. Policy Stud 37 (6):508-520. https://doi.org/10.1080/01442872.2016.1213803

Leca B, Battilana J, Boxenbaum E (2009) Agency and Institutions: a Review of Institutional Entrepreneurship. Academy of Management Annals 3:65-107 
Lombard Odier (2011) Collaboration and Partnerships: the 'swissnex' Case. Geneva

Mansell R (2018) Science diplomacy and internet governance. In: Marzouki M, Calderaro A (eds) Global internet governance as a diplomacy issue. Rowman and Littlefield, Lanham, Lanham

Margetts H, Hood C (2016) Tools Approaches. In: Peters BG, Zittoun P (eds) Contemporary approaches to public policy: theories, controversies and perspectives. Palgrave Macmillan, London, pp. 133-154

Marmier P, Fetscherin M (2010) Case E: a public-private partnership to foster science, higher education and innovation-the case of Switzerland with swissnex Boston. In: Go F, Govers R (eds) International place branding yearbook 2010: place branding in the new age of innovation. Palgrave Macmillan, pp. 97-109

Mayntz R, Scharpf FW (1995) Der Ansatz des akteurszentrierten Institutionalismus. In: Mayntz R, Scharpf FW (eds) Gesellschaftliche Selbstregelung und politische Steuerung. Campus Verlag, Frankfurt/New York, pp. 39-72

Milkoreit M (2015) Science and Climate Change Diplomacy: Cognitive Limits and the Need to Reinvent Science Communication. In: Davis LS, Patman RG (eds) Science diplomacy: new day or false dawn? World Scientific Publishing Co. Pte. Ltd., Singapore, pp. 109-131

Nye JS (2008) Public diplomacy and soft power. Ann Am Acad Pol Soc Sci 616 (1):94-109. https://doi.org/10.1177/0002716207311699

Pasternack P et al. (2016) Die BFI-Policy-Arena in der Schweiz: Akteurskonstellation in der Bildungs-, Forschungs- und Innovationspolitik, 1. BWV Berliner Wissenschafts-Verlag, Berlin, Auflage. Hochschul-und Wissenschaftsforschung Halle-Wittenberg

Powell JJW (2018) Higher education and the exponential rise of science: competition and collaboration. In: Scott RA, Buchmann M, Kosslyn SM (eds) Emerging trends in the social and behavioral sciences: an interdisciplinary, Searchable, and Linkable resource. John Wiley \& Sons, New York, pp. 1-17

Powell JJW (2020) Comparative education in an age of competition and collaboration. Comp Educ 56(1):57-78. https://doi.org/10.1080/03050068.2019.1701248

Rapley T, Rees G (2018) Collecting documents as data. In: Flick U (ed) The SAGE handbook of qualitative data collection. Sage, Los Angeles, pp. 548-565

Rüffin NV (2018) Case study science and innovation diplomacy agencies at the nexus of research, economics, and politics. Working Paper, 2018/10. https:// docs.wixstatic.com/ugd/0bc3be_f01101aa794e4a64a5158258a5bed939.pdf. Accessed 5 Jul 2018

Rüffin NV, Schreiterer U (2017) Emerging practices of diplomacy for science in europe: tensions and potentials?: Panel T05P06 Session 2 Challenges in global policy making: the 'practice turn' in the new diplomacy, Singapore. http://www. ippapublicpolicy.org/file/paper/594155d9959dd.pdf. Accessed 31 Jul 2017

Ruffini P-B (2018) The Intergovernmental Panel on Climate Change and the Science-Diplomacy Nexus. In: Kaltofen C, Acuto M, Blackstock J (eds) Special Issue: Science Diplomacy. John Wiley \& Sons Ltd, Oxford, pp. 73-77

Saurugger S (2014) The changing nature of instruments: why and how instruments of participation change in the European union. In: Halpern C, Lascoumes P, Le Galès P (eds) L'instrumentation de l'action publique: Controverses, résistances, effets. Presses de la Fondation nationale des sciences politiques, Paris, pp. 317-341

Scharpf FW (2000) Interaktionsformen: Akteurzentrierter Institutionalismus in der Politikforschung. Leske+Budrich, Opladen, UTB für Wissenschaft UniTaschenbücher Politikwissenschaft, vol 2136

Schütte G (2006) Diplomatie der Forscher: Wenn Deutschland international mithalten will, braucht es eine Außenwissenschaftspolitik. Ein Plädoyer. Die Zeit (16)

Schütte G (ed) (2008) Wettlauf ums Wissen: Außenwirtschaftspolitik im Zeitalter der Wissensrevolution. 1. Aufl. Berlin Univ. Press, Berlin

Schweizer Bundesrat (1998) 98.070 Botschaft über die Förderung von Bildung, Forschung und Technologie in den Jahren 2000-2003, 1998-505. Accessed 27 Jun 2019

Schweizer Bundesrat (2002) 02.089 Botschaft über die Förderung von Bildung, Forschung und Technologie in den Jahren 2004-2007, 2002-1417. Accessed 6 Jul 2017

Schweizer Bundesrat (2007) 07.012 Botschaft über die Förderung von Bildung, Forschung und Innovation in den Jahren 2008-2011, 2006-1630. Accessed 9 Jul 2017

Schweizer Bundesrat (2018) Internationale Strategie der Schweiz im Bereich Bildung, Forschung und Innovation: Strategie des Bundesrates, Bern. Accessed 10 Jul 2019

Schweizer Eidgenossenschaft (2016) 16.025 Botschaft zur Förderung von Bildung, Forschung und Innovation in den Jahren 2017-2020, 2015-2540

Sending OJ, Pouliot V, Neumann IB (2011) The future of diplomacy: changing practices, evolving relationships. Int J 66(3):527-542
Smelser NJ (2003) On comparative analysis, interdisciplinarity and internationalization in sociology. Int Sociol 18(4):643-657. https://doi.org/ $10.1177 / 0268580903184001$

Smith III FL (2014) Advancing science diplomacy: Indonesia and the US Naval Medical Research Unit. Soc Stud Sci 44(6):825-847. https://doi.org/10.1177/ 0306312714535864

Staatssekretariat für Bildung, Forschung und Innovation (2015) Eine Roadmap für die Weiterentwicklung des swissnex Netzwerkes: Bilanz, Perspektiven und Leitlinien. Staatssekretariat für Bildung, Forschung und Innovation, Bern

Steinmeier F-W (2008) Rede vor dem Ausschuss für Kultur und Medien des Deutschen Bundestags

Steinmeier F-W (2009) Rede zur Eröffnung der Auftaktkonferenz zur Initiative Außenwissenschaftspolitik

Stucke A (2010) Staatliche Akteure in der Wissenschaftspolitik. In: Simon D, Knie A, Hornbostel S (eds) Handbuch Wissenschaftspolitik. VS Verl. für Sozialwiss, Wiesbaden, pp. 363-376

swissinfo.ch (2000) Swiss House in Cambridge eingeweiht. https://www.swissinfo. ch/ger/swiss-house-in-cambridge-eingeweiht/1699438. Accessed16 Mar 2018

Swissnex (2016) ERI network: learn more about the swissnex network, its outposts, and the role of science and technology counsellors. https://www.swissnex.org/ about/erinetwork/. Accessed 23 May 2017

Swissnex (2019) Our mission. https://www.swissnex.org/about/mission/. Accessed 24 Jun 2019

The Royal Society, AAAS (2010) New frontiers in science diplomacy: Navigating the changing balance of power, London. Accessed 19 Jan 2017

Treib O (2015) Akteurzentrierter Institutionalismus. In: Wenzelburger G, Zohlnhöfer R (eds) Handbuch Policy-Forschung. Springer VS, Wiesbaden, pp. 277-303

Turekian VC et al. (2015) The emergence of science diplomacy. In: Davis LS, Patman RG (eds) Science diplomacy: new day or false dawn? World Scientific Publishing Co. Pte. Ltd., Singapore, pp. 3-24

Voß J-P, Simons A (2014) Instrument constituencies and the supply side of policy innovation: the social life of emissions trading. Environ Polit 23(5):735-754 https://doi.org/10.1080/09644016.2014.923625

de Wit H, Hunter F, Howard L, Egron-Polak E (2015) Internationalisation of Higher Education, Brussels. Accessed 11 Jul 2018

\section{Acknowledgements}

The author thanks her colleagues from the University of Luxembourg as well as the EduGov Team of the Hertie School for valueable feedback on earlier versions of this paper.

\section{Competing interests}

The author declares no competing interests.

\section{Additional information}

Correspondence and requests for materials should be addressed to E.E.

Reprints and permission information is available at http://www.nature.com/reprints

Publisher's note Springer Nature remains neutral with regard to jurisdictional claims in published maps and institutional affiliations.

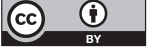

Open Access This article is licensed under a Creative Commons Attribution 4.0 International License, which permits use, sharing, adaptation, distribution and reproduction in any medium or format, as long as you give appropriate credit to the original author(s) and the source, provide a link to the Creative Commons license, and indicate if changes were made. The images or other third party material in this article are included in the article's Creative Commons license, unless indicated otherwise in a credit line to the material. If material is not included in the article's Creative Commons license and your intended use is not permitted by statutory regulation or exceeds the permitted use, you will need to obtain permission directly from the copyright holder. To view a copy of this license, visit http://creativecommons.org/ licenses/by/4.0/.

(C) The Author(s) 2020 